RESEARCH NOTE

\title{
The systematic status of Piscinema barakensis [sic] Gambhir et Ng, 2014 and Rhabdochona carpiae Nimbalkar, Deolalikar et Kamtikar, 2013, two nematodes recently described from freshwater fishes in India
}

\author{
František Moravec
}

Institute of Parasitology, Biology Centre of the Academy of Sciences of the Czech Republic, České Budějovice, Czech Republic

Abstract: Based on the original description, the nematode genus Piscinema Gambhir et Ng, 2014 and its type species, P. barakensis [sic] Gambhir et Ng, 2014 (probably a misidentified physalopterid larvae), are removed from the Philometridae, where they were allocated; they are considered a genus inquirendum and incertae sedis and a species inquirenda, respectively. The poorly described nematode Rhabdochona carpiae Nimbalkar, Deolalikar et Kamtikar, 2013 (Rhabdochonidae) appears largely fabricated and is regarded a species dubia .

Keywords: Nematoda, Philometridae, Rhabdochonidae, fish, Oriental Region

Gambhir and Ng (2014) described a new philometrid genus and species, Piscinema barakensis Gambhir et Ng, 2014, based on nematode specimens (allegedly females) found in the stomach of the catfish Bagarius sp. in Manipur, India. The specific name is malformed, since the generic name is neuter. The species description is poor, but it is apparent from the text and illustrations that these nematodes possess a functional anus and rectal glands and, consequently, do not belong to the family Philometridae Baylis et Daubney, 1926, where they were placed. This is supported by the fact that they were found in the host's stomach, whereas all philometrids are tissue or body cavity parasites. The general morphology (especially the structure of the cephalic end) and measurements of these indicate that may be in fact infective larvae belonging to the family Physalopteridae Railliet, 1893. Therefore, S. barakense [emend.] is considered to be a species inquirenda. Since it is the type species of Piscinema Gambhir et Ng, 2014, this genus should be considered a genus inquirendum and incertae sedis.

Nimbalkar et al. (2013) erected a new nematode species Rhabdochona carpiae Nimbalkar, Deolalikar et Kamtikar, 2013 based on specimens from the intestine of the common carp Cyprinus carpio Linnaeus in Aurangabad, India. The description is rather confused and it seems probable that the text of this description was partly 'adapted' from the papers of other authors. Moreover, all of the line drawings purported to be $R$. carpiae are in fact those previously published by Moravec et al. (2010) (see fig. E and F in Nimbalkar et al. 2013) for R. hellichi turkestanica (Skryabin, 1917) and by Moravec and Kamchoo (2012) (see fig. A-D in Nimbalkar et al. 2013) for R. rasborae Moravec et Kamchoo, 2012. Due to the evident plagiarism and serious mistakes in the description of this alleged new species, $R$. carpiae should be considered a species dubia.

The author's attempts to borrow the type specimens of both $P$. barakense [emend.] and $R$. carpiae for a re-examination were unsuccessful.

\section{References}

Gambhir R.K., NG Z. 2014: A new nematode of the family - Philometridae from a catfish in Manipur, India. J. Exp. Zool. India 17: 111-114.

Moravec F., Kamchoo K. 2012: Description of Rhabdochona (Globochona) rasborae sp. n. (Nematoda: Rhabdochonidae) from the freshwater cyprinid fish Rasbora paviana Tirant in southern Thailand. Folia Parasitol. 59: 209-215.

Moravec F., Scholz T., Ash A., Kar P.K. 2010: New data on the morphology and taxonomy of three species of Rhabdochona

(Nematoda: Rhabdochonidae) parasitizing fishes in India. Folia Parasitol. 57: 295-306.

Nimbalkar R.K., Deolalikar R.V., Kamtikar V.N. 2013: New species of Rhabdochona, Cyprinus carpio (L.) in Jaikwadi Dam of Aurangabad (M. S.) India. Biosci. Disc. 4: 245-249.

Received 29 April 2014

Accepted 8 May 2014

Address for correspondence: F. Moravec, Institute of Parasitology, Biology Centre of the Academy of Sciences of the Czech Republic, Branišovská 31, 37005 České Budějovice, Czech Republic. Phone: +420 38777 5432; Fax: +420 38531 0388; E-mail: moravec@paru.cas.cz 